\title{
PENATALAKSANAAN HIPERPLASIA GINGIVA DISEBABKAN OLEH PENGGUNAAN AMLODIPINE: Sebuah Laporan Kasus
}

\author{
Arni Irawaty Djais *), Lilies Anggarwati Astuti **) \\ *) Departement of Periodontics, Faculty of Dentistry, Hasanuddin University \\ **) Periodontics Residency Program, Faculty of Dentistry, Hasanuddin University \\ Email : liliesanggarwatigauk@yahoo.com
}

\begin{abstract}
Introduction: gingival hyperplasia is a result of administration from some anticonvulsant drugs, immunosuppressants, and calcium channel blockers that well known can cause problems when speaking, mastication, tooth eruption, and aesthetic. Calcium channel blockers are a class of drugs developed for the care of cardiovascular conditions. Some of these drugs can cause gingival enlargement. Case: A 55-year-old female patient came to Periodontal Department of Hasanuddin University Dental Hospital,Makassar. Patients present with a less comfortable and did not feel confident with the condition of the front of the upper jaw gums since three months ago. These symptoms begin to be felt since taking drugs for hypertension disease with amlodipine with $10 \mathrm{mg} 1$ time a day. The patient began to feel a change in the form of excessive enlargement of the gums almost the entire upper jaw teeth. Management of Case: Disinfection area of operation, anesthesia with lidocaine 2\% of nor epinephrine, marking the pocket using the pocket marker basis, incision using Krickland knife, removal of gingiva using papilla Orban knife and performed by scaling and root planing, periodontal pack was used. Conclusion: Patients who took the drug amlodipine as calcium channel blocker classification in the long-term directly effects the growth of excess gingival tissue, causing gingival enlargement.
\end{abstract}

Keyword: Hyperplasia Gingiva, Amlodipine

\section{PENDAHULUAN}

Hiperplasia gingiva merupakan salah satu akibat pemberian beberapa obat-obatan antikonvulsan, imunosupresan, dan calcium channel blockers yang diketahui dengan baik dapat menimbulkan masalah saat berbicara, mastikasi, erupsi gigi, dan estetik. Ciri klinis dan mikroskopik pembesaran yang disebabkan oleh obat yang berbeda sangat serupa. ${ }^{1}$ Pertumbuhan gingiva dimulai sebagai pembesaran papilla interdental yang nyeri dan serupa manik-manik, meluas dari marginal gingiva fasial dan lingual. Seiring dengan perkembangan kondisi penyakit, pembesaran marginal dan papilla bersatu kemudian berkembang menjadi lipatan jaringan masif yang menutupi sebagian mahkota gigi; 
Penatalaksanaan Hiperplasia Gingiva Disebabkan Oleh Penggunaan Amlodipine: Sebuah Laporan Kasus

pembesaran tersebut dapat mengganggu oklusi. ${ }^{1}$

Ketika tidak dipengaruhi oleh inflamasi, lesi berbentuk mulberry, kaku, berwarna merah muda pucat, dan resilient, disertai permukaan berbentuk lobulated dan tanpa kecenderungan perdarahan.

Pembesaran ini memiliki ciri dengan tampilan yang menonjol dari balik marginal gingiva, yang dipisahkan oleh groove linear. Namun, adanya pembesaran menyebabkan kontrol plak menjadi lebih sulit, kadang menyebabkan proses inflamasi sekunder yang semakin memperrumit pertumbuhan gingiva berlebih akibat obat-obatan. ${ }^{1,2}$

Pembesaran tersebut kemudian menjadi kombinasi peningkatan ukuran yang disebabkan oleh obat-obatan dan komplikasi inflamasi yang disebabkan oleh bakteri. Perubahan inflamasi sekunder tidak hanya menambah ukuran lesi yang diakibatkan oleh obatobatan, namun juga memperlihatkan diskolorasi berwarna merah atau merah kebiruan, menghilangkan batas permukaan lobulated, dan peningkatan kecenderungan perdarahan. ${ }^{2}$ Pembesaran akibat obat-obatan dapat terjadi pada rongga mulut dengan plak yang sedikit atau bahkan tidak ada sama sekali, dan tidak terlihat pada rongga mulut dengan deposit plak yang menumpuk. Beberapa peneliti meyakini bahwa inflamasi merupakan prasyarat perkembangan pembesaran dimana oleh karenanya dapat dicegah dengan menghilangkan plak dan pembersihan rongga mulut yang sangat teliti. Pembersihan rongga mulut dengan cara menyikat gigi atau menggunakan pasta gigi chlorhexidine dapat mengurangi inflamasi namun tidak mengurangi atau mencegah pertumbuhan yang berlebih. Hassell dkk telah berhipotesis bahwa pada gingiva yang tidak mengalami inflamasi, fibroblas kurang aktif atau bahkan tidak bergerak dan tidak merespon terhadap phenytoin yang bersirkulasi, sedangkan fibroblas yang berada di dalam jaringan terinflamasi berada pada tahap aktif sebagai hasil dari mediator inflamasi dan adanya faktor pertumbuhan endogen. ${ }^{1,2}$

Pembesaran mengalami peningkatan ukuran secara perlahan dan bersifat kronis. Ketika pembesaran tersebut dihilangkan secara pembedahan, pembesaran akan kambuh kembali. Menghilangnya pembesaran secara spontan terjadi dalam beberapa bulan setelah pemberhentian penggunaan obat. $^{3}$

Pembesaran gingiva akibat penggunaan obat terdiri atas 
Penatalaksanaan Hiperplasia Gingiva Disebabkan Oleh Penggunaan Amlodipine: Sebuah Laporan Kasus

hiperplasia jaringan ikat dan epitel yang menonjol. Terjadi akantosis epitel dan rete pegs yang memanjang meluas jauh ke dalam jaringan ikat, yang tampak memadat menyusun rangkaian kolagen disertai peningkatan jumlah fibroblas dan pembuluh darah baru. Zat dasar amorfik yang melimpah juga terlihat. Perubahan struktural pada permukan sel epitel bagian luar dilaporkan pada pembesaran yang disebabkan oleh cyclosporine. $^{3,4}$

Pembesaran berawal seperti hiperplasia inti jaringan ikat marginal gingiva dan meningkat akibat proliferasi dan ekspansi jaringan ikat melebihi puncak marginal gingiva. Infiltrasi inflamasi dapat ditemukan pada dasar sulkus atau poket. Pembesaran cyclosporine biasanya memiliki jaringan ikat yang sangat tervaskularisasi disertai foci sel inflamasi kronis, terutama sel plasma. ${ }^{4}$

Pembesaran phenytoin mature memiliki rasio fibroblas/kolagen yang sama dengan gingiva normal dari individu normal, menunjukkan bahwa pada beberapa titik dalam perkembangan lesi, proliferasi fibroblastik terjadi sangat tidak normal. Pembesaran phenytoin yang kambuh kembali tampak sebagai jaringan granulasi yang terdiri atas sejumlah kapiler dan fibroblas muda, fibril kolagen yang tersusun tidak teratur kadang disertai limfosit. ${ }^{4}$

Calcium channel blockers merupakan obat yang dikembangkan untuk perwatan kondisi kardiovaskular seperti hipertensi, angina pektoris, spasme arteri koroner, dan aritmia jantung. Obat-obatan tersebut menghambat influks ion kalsium di sepanjang membran sel jantung dan sel otot halus, menghambat mobilisasi intraseluler kalsium. Hal tersebut menyebabkan pembesaran arteri koroner dan arteriol secara langsung, memperbaiki suplai oksigen menuju otot jantung; juga menurunkan hipertensi dengan memperbesar vaskularisasi perifer. ${ }^{1,4}$

Obat-obatan

tersebut merupakan derivat dihydropiridine (amlodipine (Lotrel, Norvasc), felodipine (Plendil), nicardipine (Cardene), nifedipine (Adalat, Procardial)), derivat benzothiazine (diltiazem (Cardizem, Dilacor XR, Tiazac)), dan derivat phenylalkylamine (verapamil (Calan, Isoptin, Verelan, Covera HS)). ${ }^{1,2,5}$

Beberapa obat-obatan tersebut dapat menyebabkan pembesaran gingiva. Nifedipine, salah satu obatobatan yang kadang digunakan, menyebabkan pembesaran gingiva 
Penatalaksanaan Hiperplasia Gingiva Disebabkan Oleh Penggunaan Amlodipine: Sebuah Laporan Kasus

pada $20 \%$ pasien. Diltiazem, felodipine, nitrendipine, dan verapamil juga menyebabkan pembesaran gingiva. Derivat dihydropiridine, isradipine, dapat menggantikan nifedipine pada beberapa kasus dan tidak menyebabkan pertumbuhan gingiva berlebih. ${ }^{1,5}$

Nifedipine juga digunakan bersamaan dengan cyclosporine pada penerima transplantasi ginjal, dan kombinasi penggunaan kedua obat tersebut menyebabkan pertumbuhan berlebih yang lebih besar. Pembesaran gingiva nifedipine secara eksperimen telah terbukti pada tikus, yang tampak bergantung pada dosis; pada manusia, bagaimanapun, ketergantungan dosis masih belum jelas. Salah satu laporan menunjukkan bahwa nifedipine meningkatkan risiko kerusakan periodontal pada pasien dengan diabetes mellitus tipe $2{ }^{2}$

\section{KASUS}

Seorang pasien wanita berumur 55 tahun datang ke bagian periodonsia RSGM Unhas Makassar. Pasien datang pada bulan Mei 2014 dengan keluhan utama kurang nyaman dan merasa tidak percaya diri dengan kondisi gusi bagian depan rahang atas sejak tiga bulan lalu. Gejala ini mulai dirasakan sejak mengonsumsi obatobatan untuk penyakit hipertensi yang diderita yaitu amlodipine dengan dosis 10 mg 1 kali sehari. Awalnya pasien merasakan gusi bengkak hanya diantara dua gigi depan saja, namun setelah pasien mengalami stroke, pasien mulai merasakan perubahan yang berlebih berupa pembesaran gusi hampir seluruh gigi rahang atas. Dosis obat yang dikonsumsi ditambah oleh dokter internis. Pasien sering memeriksakan diri ke dokter internis untuk mengontrol tekanan darahnya dan pasien akhirnya mengonsumsi obat amlodipine kurang lebih 10 tahun. Pada pemeriksaan ektra oral tidak terdapat kelainan. Pada pemeriksaan klinis (Gambar 1) terdapat gusi bengkak pada regio anterior, posterior (labial, bukal, palatal) rahang atas kanan. Gingiva terlihat udem, hiperemi yang hampir menutupi seluruh permukaan mahkota gigi. Terdapat poket gigi $11,12,13,14,15,16,21,22$ sekitar $5 \mathrm{~mm}$. Tidak terlihat adanya kalkulus pada permukaan gigi maupun gingiva. Oklusi gigi-gigi anterior rahang atas dan gigi-gigi anterior rahang bawah tidak ada keluhan. Efek penggunaan obat ini juga mulai terlihat mengenai gingiva rahang bawah anterior. Pada pemeriksaan radiografi tidak terlihat kehilangan tulang yang menyebabkan gigi goyang. (Gambar 2) 


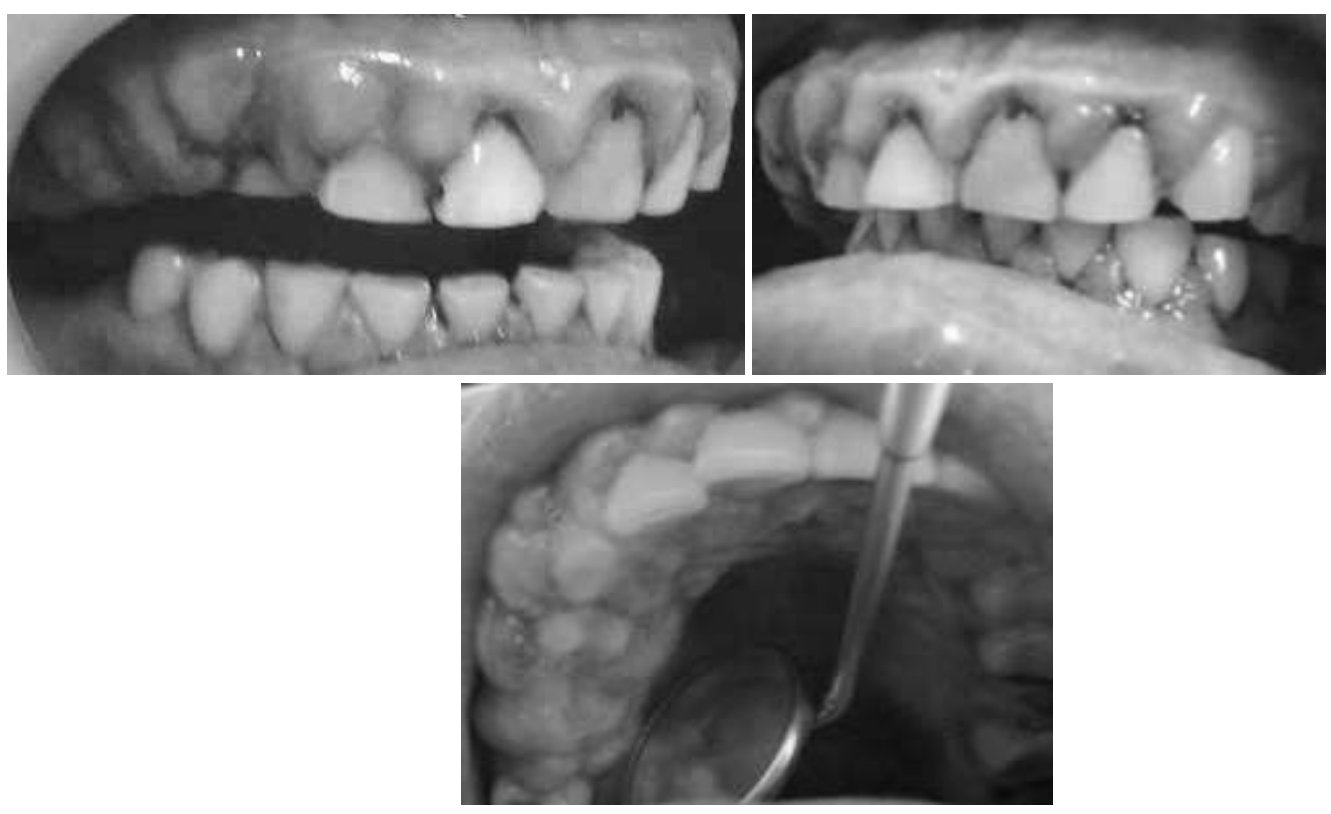

Gambar 1. Pemeriksaan Klinis

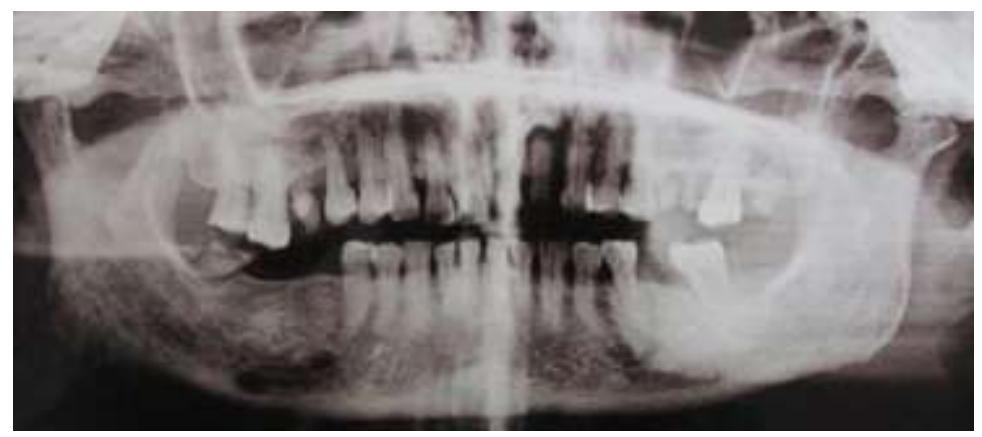

Gambar 2. Pemeriksaan Radiografi

\section{PENANGANAN KASUS}

Sebelum dilakukan tindakan perawatan berupa gingivektomi, pasien dikonsul ke bagian internis untuk mengontrol tekanan darah dan melakukan beberapa pemeriksaan sehingga perawatan yang dilakukan aman untuk kondisi sistemik pasien. Setelah seminggu, pasien datang kembali dengan membawa hasil pemeriksaan laboratorium, EKG, pengobatan yang diberikan oleh internis, hingga anjuran untuk pasien tersebut. Dari hasil konsul, internis menghentikan penggunaan obat amlodipine yang selama ini dikonsumsi oleh pasien dan menggantinya dengan obat Catapres (Clonidine HCL) 150 mcg, Canderin (Candesartan cilexetil $16 \mathrm{mg}$ ) serta anjuran berupa dibolehkannya dilakukan tindakan operasi dengan anestesi lokal nor epinefrin jika tekanan darah pasien kurang dari 140/90 mmHg. Pasien 
Penatalaksanaan Hiperplasia Gingiva Disebabkan Oleh Penggunaan Amlodipine: Sebuah Laporan Kasus

sebelumnya dijelaskan prosedur meminta persetujuan dengan perawatan yang akan dilakukan dan menandatangani informed concent.

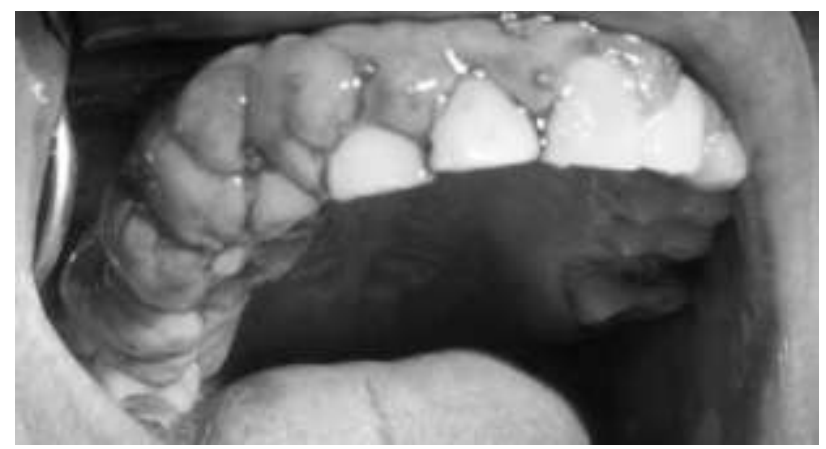

Gambar 3. Desinfeksi

Awalnya dilakukan desinfeksi hingga ke palatal dengan pada seluruh regio anteroposterior menggunakan betadine. (Gambar 3).

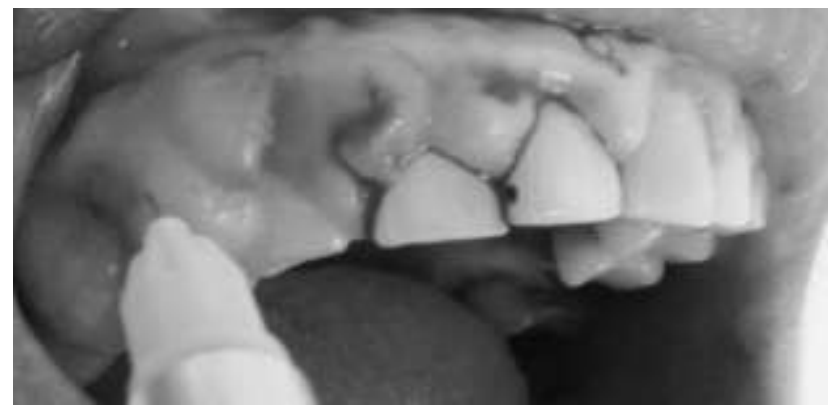

Gambar 4. Injeksi Anestesi Lokal

Dilakukan injeksi anestesi lokal seluruh daerah yang akan dioperasi. berupa lidocaine 2\% nor epinefrin ke (Gambar 4).

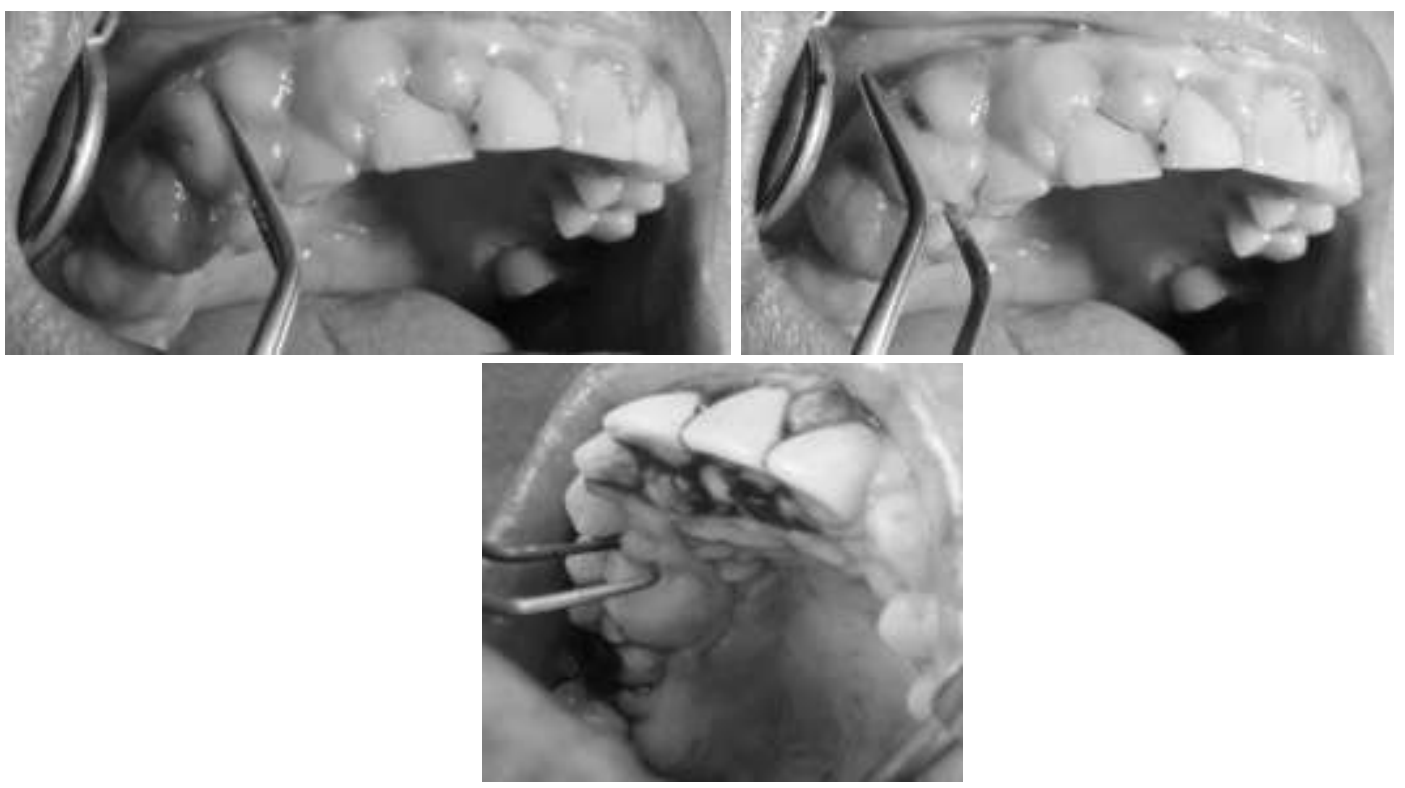

Gambar 5. Bleeding Point Regio Labial, Bukal dan Palatal 
Penatalaksanaan Hiperplasia Gingiva Disebabkan Oleh Penggunaan Amlodipine: Sebuah Laporan Kasus

$$
\text { Menandai dasar poket permukaan gingiva yang mengalami }
$$
menggunakan pocket marker sehingga pembesaran sebagai acuan dilakukan didapatkan bleeding point disetiap gingivektomi. (Gambar 5).

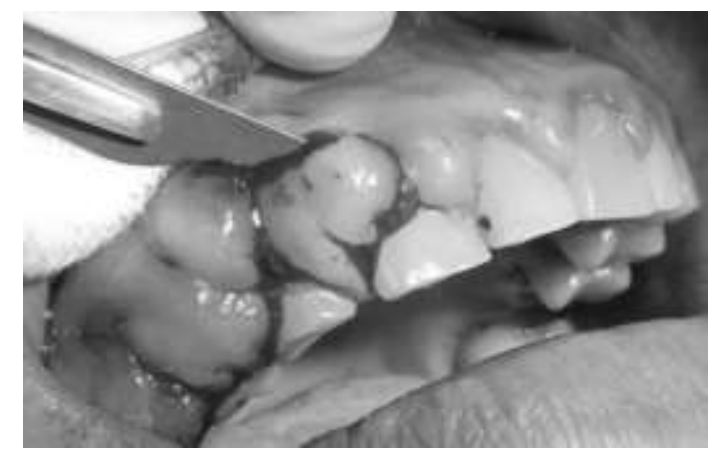

Gambar 6. Insisi

Dilakukan insisi menggunakan no.15 pada bleeding point yang telah Krickland knife dibantu oleh blade didapatkan sebelumnya. (Gambar 6).

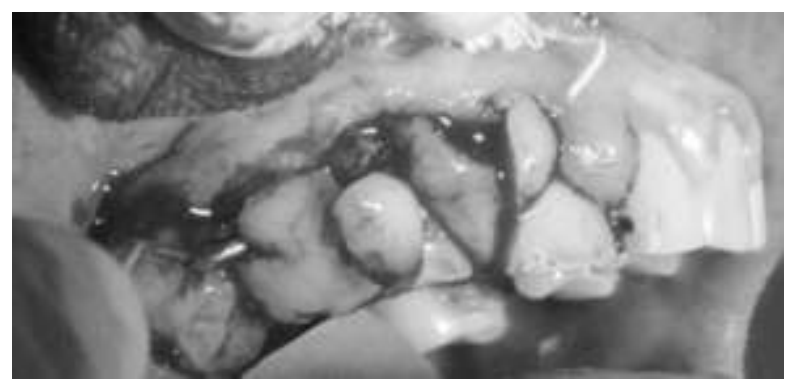

Gambar 7. Pengambilan Jaringan Gingiva

Dilakukan pengambilan gingiva dilakukan skeling dan root planning. yang telah dilakukan insisi sebelumnya (Gambar 7).

menggunakan Orban papilla knife dan
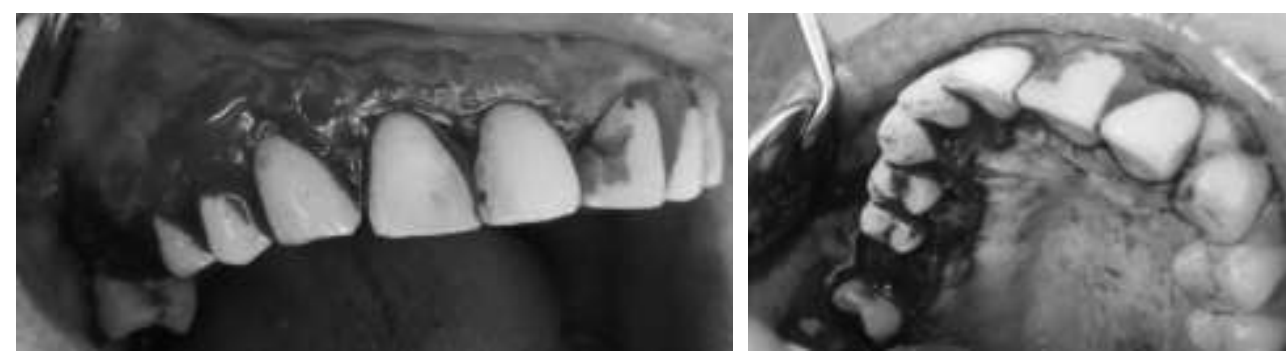

Gambar 8. Setelah Gingivektomi

Tampak terlihat permukaan anteroposterior kanan atas. (Gambar mahkota gigi yang lebih jelas setelah 8).

dilakukan gingivektomi pada regio 
Penatalaksanaan Hiperplasia Gingiva Disebabkan Oleh Penggunaan Amlodipine: Sebuah Laporan Kasus

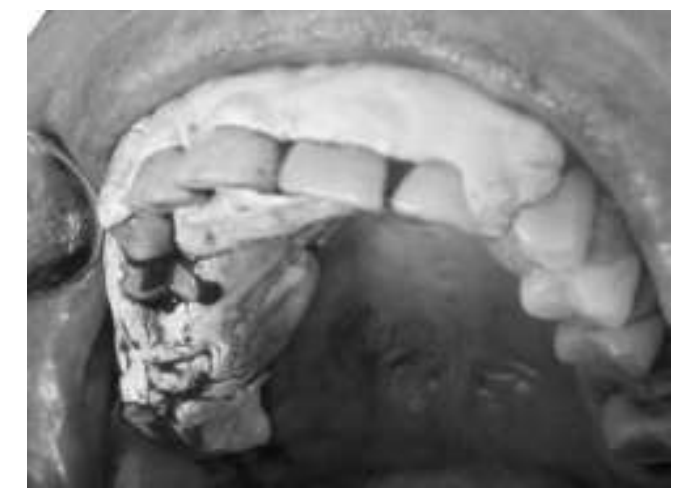

Gambar 9. Pemasangan Periodontal Pack

Terakhir dilakukan pemasangan gingivektomi. Hasil jaringan gingiva periodontal pack (Gambar 9) pada yang telah diambil. (Gambar 10). seluruh daerah yang telah dilakukan

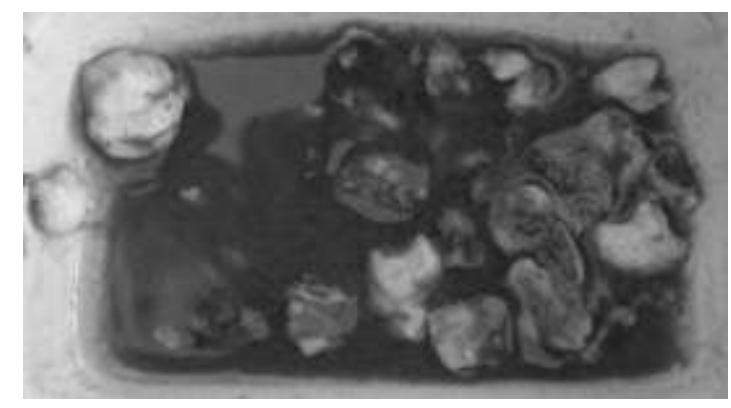

Gambar 10. Jaringan Gingiva
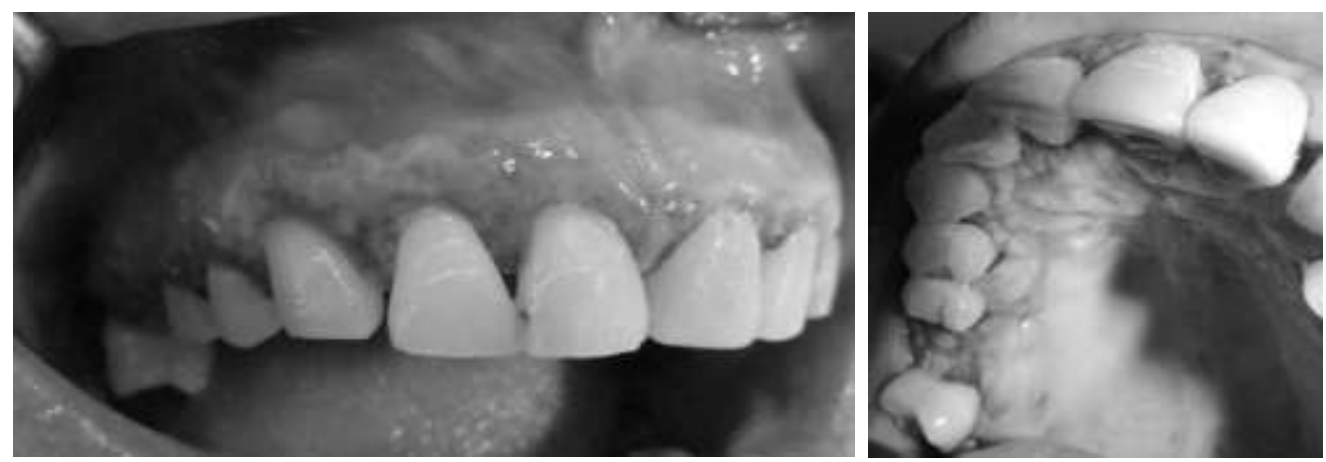

Gambar 11. Kontrol POD IV

Kontrol POD IV regio labial, menggunakan $\mathrm{NaCl}$, diberikan bukal dan palatal setelah dilakukan periodontal pack kembali serta gingivektomi terlihat masih hiperemi, dijadwalkan untuk kontrol seminggu kemudian dilakukan irigasi dengan berikutnya. (Gambar 11). 

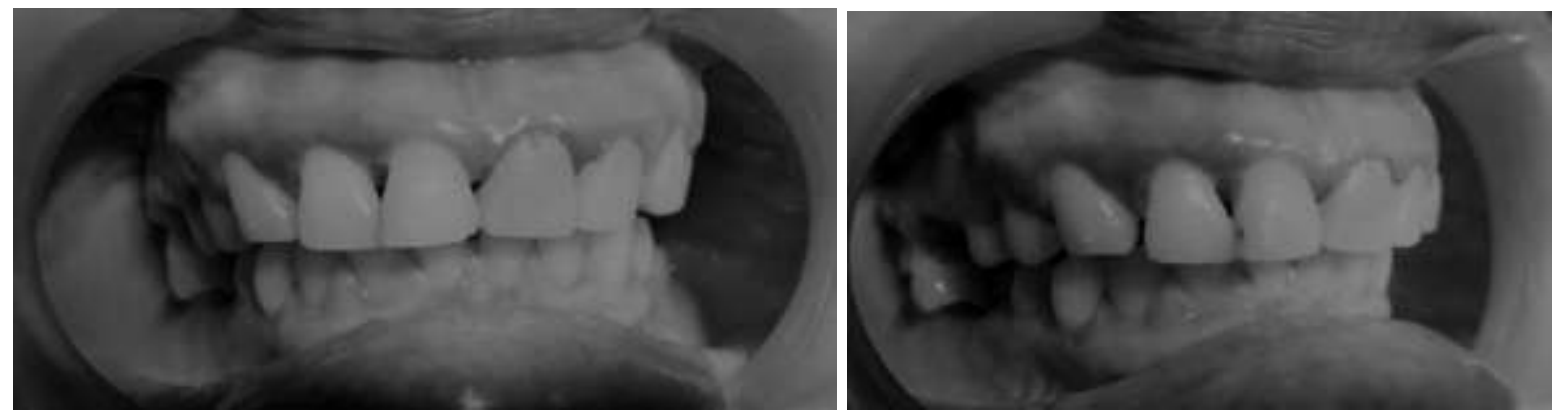

Gambar 12. Kontrol POD XII

Kontrol POD XII terlihat gingiva

telah mengalami penyembuhan tanpa hiperemi dan attached gingiva melekat

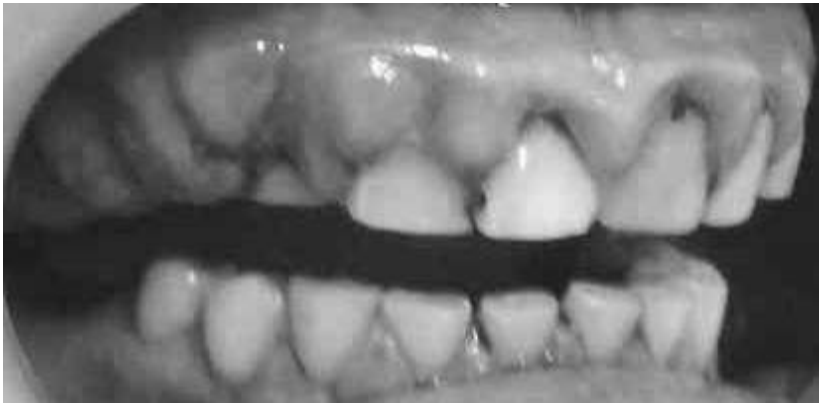

pada permukaan gigi. Pasien juga telah merasa nyaman dengan kondisi gingiva saat ini. (Gambar 12).

Gambar 13. Pre Operatif (kiri) dan Post Operatif 4 bulan (kanan)

Tampak perubahan kontur pada permukaan gingiva pada kontrol 4 bulan setelah dilakukan gingivektomi, tidak terjadi rekuren hiperplasia gingiva, attached gingiva terbentuk dengan baik pada permukaan gigi, dan pasien telah merasa sangat nyaman. (Gambar 13).

\section{KESIMPULAN}

Pentingnya pemberian edukasi pada pasien yang menggunakan obatobatan dalam jangka panjang dengan

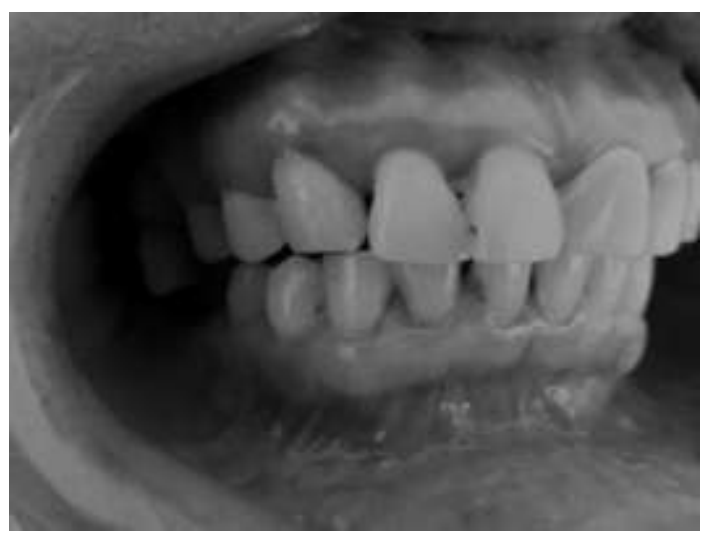

riwayat sistemik sehingga dapat mencegah efek samping pada rongga mulut. Pasien yang menggunakan obat amlodipine golongan Calcium channel blockers dalam jangka panjang memberikan efek langsung pada pertumbuhan jaringan gingiva yang berlebih sehingga menyebabkan pembesaran gingiva. Komunikasi yang baik antara dokter gigi dengan dokter internis dalam pemberian perawatan yang terintegrasi memberikan prognosis yang baik. 
Penatalaksanaan Hiperplasia Gingiva Disebabkan Oleh Penggunaan Amlodipine: Sebuah Laporan Kasus

\section{DAFTAR PUSTAKA}

Carranza FA, Camargo PM, Takei HH. 2011. Gingival Enlargement.In: Dolan J, editor. Carranza's Clinical Periodontology. $11^{\text {th }}$ Ed. China: Saunders Elsevier: 84-9. 556-57.

Kinane DF, Lindhe J, Trombelli L. 2008. Drug-influenced gingival enlargement. In: Lindhe J, Lang NP, Karring $\mathrm{T}$, editors. Clinical Periodontology and Implant Dentistry. $5^{\text {th }}$ Ed. Oxford: Blackwell Munksgaard: 410-13, 641, 804-18.

Walter B.Hall. 2003. Treatment of Gingival Enlargement. In:
William P. Lundergan. Critical Decisions in Periodontology. $4^{\text {th }} \quad$ Ed. BC Decker Inc:Hamilton London 58, 13840.

Srivastava K Amit,etc. Management of amlodipine-induced gingival enlargement: Series of three cases. $J$ Indian Soc Periodontol. 2010 Oct-Dec; 14(4): 279-281.

Sharma Shivani, Sharma Anamika. Amlodipine-Induced Gingival Enlargement:A Clinical Report. Review article Aegis Communication. 2012 May: Vol.33, Issue 5:3-9. 